\section{Карина ШАХБАЗЯН}

\section{Основні напрямки реформування правового регулювання інформаційного суспільства в Свропі. Реформування права інтелектуальної власності}

\begin{abstract}
Стаття присвячена масштабним змінам і вдосконаленню правового регулювання єдиного європейського ринку, і особливо його цифрового сегменту. Розглянуті напрямки такого реформування - розвиток економіки даних і онлайн бізнес-проектів, доступність контенту користувачам, захищеність інтересів авторів. Визначені нові регламенти, директиви і повідомлення Свропейської комісії з аналізом ринків і оцінкою змін. Розглянуто також істотне оновлення законодавства про авторське та суміжні права, визначені напрямки адаптації законодавства України до права ЄС.

Ключові слова: право інтелектуальної власності $Є С$, реформа авторського права, правове регулювання інформаційного суспільства в Європі, право інтелектуальної власності України, Директиви СС.
\end{abstract}

The article is devoted to the large-scale changes and improvement of legal regulation of the single European market, and especially its digital segment. The directions of such reform are considered - development of data economy and online business projects, accessibility of content to users, protection of interests of the authors.

Keywords: EU intellectual property rights, EU copyright reform, legal regulation of information society in Europe, intellectual property rights of Ukraine, EU directives.

Огляд реформи європейського права.

У 2015 р. Євросоюз анонсував масштабну програму, покликану поліпшити роботу єдиного європейського ринку [1], і особливо його цифрового сегменту [2]. Завдання - розвиток економіки даних і онлайн бізнес-проектів, доступність контенту користувачам, захищеність інтересів авторів. Підготовлено два десятки нових регламентів, директив і повідомлень Свропейської комісії, величезний масив супровідних матеріалів з детальним аналізом ринків і оцінкою обговорюваних змін. У числі інших заходів - заплановано серйозне оновлення законодавства про авторське та суміжні права.

Основні документи визначають стратегію побудови Єдиного цифрового ринку і включають проекти реформування:

- авторського і суміжного права;

- правил регулювання цифрових контрактів;

- принципів примусового здійснення авторських прав і прав споживачів.

Вважається, що період активної законотворчості в Свросоюзі закінчився кілька років тому, оскільки масштабні акти перестали з'являтися. Законодавець поступився ініціативою Суду СС, який продовжив гармонізувати право через тлумачення, що мало досить фрагментарний характер, а посадові особи та правознавці наголошували на необхідності проведення реформи авторського права. Європейська комісія, згідно планів проводила численні публічні консультації та обмін думками, в ході яких фахівці та інші зацікавлені особи давали коментарі [3]. Окремі вузькоспрямовані директиви (про сирітські твори або колективне управління) додавались до політики СС в сфері інтелектуального права. Нарешті, в 2015 р. Європейська Комісія опублікувала два важливих Повідомлення: «Стратегія Цифрового Сдиного Ринку для Європи» $\mathrm{i}$ «У напрямку до сучасного, більш європейсько-

УДК 341.9

https://doi.org/10.36952/ujil.2019.4.135

(C) К. Шахбазян, 2019

\section{ШАХБАЗЯН Карина Суренівна} кандидат юридичних наук, учений секретар Центру інтелектуальної власності та трансферу технологій НАН України 
го авторського права», за якими було розроблено кілька нових регламентів і директив та проектів щодо цифрової сфери в ЄС.

Повідомлення Сврокомісії від 06.05.2015 р. «Стратегія Цифрового Сдиного Ринку для Свропи» [4] (Communication A Digital Single Market Strategy for Europe).

Інтернет та цифрові технології, перетворившись 3 окремого сектора економіки в основу всієї інноваційної економічної системи, змінюють спосіб життя і роботи кожної людини, підприємства, суспільства в цілому. Створювані національні цифрові ринки будуть більш ефективні у вигляді єдиного європейського ринку. Цифровий єдиний ринок (Digital Single Market, DSM) - ринок, на якому забезпечується вільне переміщення товарів, трудових ресурсів, послуг, капіталів, і на якому фізичні особи і підприємства можуть в рівній мірі отримувати доступ і вести діяльність он-лайн на умовах справедливої конкуренції, високого рівня охорони прав споживачів і персональних даних, а також незалежно від їх громадянства або місця знаходження.

В основу Стратегії DSM поставлені 3 принципи: забезпечення кращого доступу споживачів і бізнесу до онлайн товарів і послуг по всій Свропі; створення умов для розвитку IT-мереж і контент-послуг; підвищення потенціалу зростання європейської цифрової економіки.

Серед заходів щодо покращення доступу он-лайн Сврокомісія вказує наступні:

- Стимулювання більш активного залучення учасників в електронну комерцію за рахунок підвищення їх довіри один до одного.

- Зручність укладання онлайн угод слід доповнити ефективною системою транскордонної доставки посилок [5]. У травні 2016 р ЄK представила проект спеціального Регламенту (Regulation on cross-border parcel delivery services) [6].

- Заборона обмежувати доступ за географічною ознакою. ${ }^{1}$

- Кращий доступ до цифрового контенту.

Створення належних умов і рівних правил для розвитку мереж і інноваційних сервісів:

- Вдосконалення правил для кампаній з надання послуг в сфері телекомунікацій.

- Оновлення норм, що регулюють поширення медіа-контенту.

- Оновлення правил для он-лайн платформ і посередників.

- Відновлення довіри і безпеки в цифрових сервісах і при обробці персональних даних.

- Збільшення потенціалу зростання цифрової економіки (основний напрямок - цифровізація всіх секторів економіки. Вдосконалення електронної інфраструктури дасть прискорення цифрової економіки і посилить залучення соціуму (е-уряд, охорона здоров'я, транспорт і т.д.). Включає побудову економіки даних, підвищення конкурентоспроможності через сумісність і стандартизацію, інклюзивне e-society, цифровізацію галузей (цьому присвячено Повідомлення СК від 19.04.2016 р. “Цифровізація європейської промисловості”).

Другий програмний документ щодо Сдиного ринку Свропейська комісія опублікувала 28 жовтня 2015 р. - Повідомлення «Модернізація Сдиного ринку: більше можливостей для людей і бізнесу» (Upgrading the Single Market: more opportunities for people and business) [7].

У ньому описується безліч кроків, які допоможуть розвитку єдиного європейського ринку. Більшість $з$ них не стосуються цифрової сфери або інтелектуальної власності, тому зупинимось лише на двох.

1) Важливу частину нової економіки займає економіка спільного використання. Вона зачіпає безліч приватних осіб, які активно залучаються до комерції, створює нові бізнес-моделі, змінює звичні способи поводження з трудовими ресурсами та активами, вимагає збалансованого регулювання онлайн платформ та інших цифрових інструментів. Отже, існує потреба в новому законодавстві. СК готує окремий документ з рекомендаціями, як пристосувати чинне законодавство під нові завдання. Це зроблено в Повідомленні від 02 червня 2016 г. «Європейський порядок денний для економіки спільного використання» (Communication «A European agenda for collaborative economy») [8].

2) Деякі пропозиції стосуються права інтелектуальної власності. Галузі, в яких використовуються права інтелектуальної власності, забезпечують 39\% ВВП ЄС і 35\% робочих місць. Слідом за успішним запуском єдиної патентної системи Сврокомісія вважає доцільним впровадити єдиний європейський режим свідоцтв додаткової охорони (supplementary protection certificate).

В грудні 2015 р. опублікований проект «Директиви про певні аспекти договорів поставки цифрового контенту» (Proposal for a Directive on certain aspects concerning contracts for the supply of digital content) [9]. Сьогодні спеціальне законодавство про продаж цифрового контенту є лише в кількох державах-членах СС (напр., у Великобританії, Нідерландах).

\footnotetext{
${ }_{1}^{1}$ Якщо підприємець обмежує доступ споживачів з інших держав-членів до обраних ними версій сайту або перенаправляє їх на інші версії (зокрема, реалізуючи цінову дискримінацію) виключно через місця проживання споживачів (unjustified geo-blocking), то такі дії ведуть до сегментації ринків і незадоволеності споживачів.
} 
В Директиві надається визначення цифрового контенту; вона застосовуватиметься до всіх договорів, за якими в обмін на цифровий контент споживач надає гроші, персональні дані або будь-яку іншу інформацію; Директива має імперативний характер - держави-члени не мають права приймати норми, що відрізняються, навіть з метою досягнення іншого рівня захисту споживачів; визначені умови передачі цифрового контенту та підходи щодо визначення його відповідності умовам договору; підходи щодо успішної інтеграції контенту до цифрового середовища покупця; визначені права споживача; визначено, хто несе відповідальність за завдання майнової шкоди та умови розірвання договору.

Основні напрямки реформування права інтелектуальної власності в Свропі.

Після загального огляду підготовлених Європейською комісією змін до законодавства щодо регулюванні цифровий сфери, варто розглянути, які новації пропонуються щодо авторського і суміжного права. Вони переважно викладені в пакеті документів, опублікованих Єврокомісією 14 вересня 2016 p.

Експерти і користувачі намагались визначити, чи це є реальна реформа, чи шукає європейський законодавець реальний баланс інтересів учасників.

Попередній план дій був намічений ще в Повідомленні Сврокомісії від 09 грудня 2015 г. «У напрямку до сучасного, більш європейського авторського права» («Towards a modern, more European copyright framework») [10]. Він складається з 4 основних кроків.

1) Забезпечення широкого доступу до контенту на всій території ЄС.

В Свропі найбільший відсоток користувачів Інтернету серед населення (77\%) в порівнянні 3 іншими країнами. Сврокомісія пропонує поступово усувати перешкоди, що заважають транскордонному доступу до контенту і поширенню творів.

Намічені кроки:

- забезпечення мобільності контенту, щоб користувачі, які оформили передплату або придбали контент, могли зберігати доступ до нього при тимчасових поїздках в інші країни СС;

- сприяння он-лайн транскордонному поширенню ТБ- і радіопрограм;

- стимулювання видачі транскордонних ліцензій на використання контенту шляхом розробки програм медіації і т.п.;

- спрощення оцифровки творів, що вийшли з комерційного обороту, і надання до них доступу на всій території ЄС;

- заходи з просування європейських творів на єдиному ринку, включаючи каталоги фільмів, створення ліцензійних хабів, широке застосування стандартизованих ідентифікаторів творів, щоб потенційним споживачам і інвесторам було легше відшукувати необхідні матеріали;

- $\quad$ розробка європейського агрегатора пошукових онлайн-сервісів (для індексації доступних правомірних пропозицій контенту) і національних пошукових інструментів; поліпшення фінансування виготовлення субтитрів і дубляжу за рахунок публічних фондів;

- обговорення $з$ аудіовізуальної індустрією способів поліпшення фінансування європейських творів.

2) Адаптація виключення з права IB на цифрову та транскордонну територію.

Фрагментацію авторського права в СС можливо прослідкувати за прикладом вилучень і обмежень. Норми про вилучення в праві СС переважно недеталізовані. Національні законодавці самі вирішують, в якій мірі їх імплементувати. Імперативних норм всього дві: в ст. 5 (1) Директиви про інформаційне суспільство [11] і в ст. 6 Директиви про сирітські твори. Тому не в усіх державах СС $є$ виключення, або умови їх застосування різняться. Інколи вилучення в національному праві визначено більш вузько, ніж в праві СС. Суд СС намагається узагальнити пратику, пояснюючи тим, що держави ЄС повинні гармонізувати підходи до визначення меж вилучень, встановлених правом ЄС. Суд ЄС також роз'яснив, що, оскільки виключення слід тлумачити суворо, держави ЄС зобов'язані зберегти їх дієвість. Нарешті, самі винятки (вилучення) слід періодично переглядати через зміни технологій. Тому основна мета - підвищити рівень гармонізації, зробити положення про винятки обов'язковими і забезпечити їх функціонування на всій території ЄС.

Заплановані етапи:

- імплементувати Маракешський договір;

- дозволити публічним дослідницьким організаціям, що діють в суспільних інтересах, здійснювати глибинний аналіз тексту та даних, до яких вони мають правомочний доступ;

- пояснити обсяги винятку «ілюстрація для цілей навчання», а також його застосування в цифровій сфері та при онлайн-навчанні;

- уточнити правила збереження культурної спадщини, в т.ч. 3 використанням цифрових технологій, а також з оригіналу цифрового або оцифрованого контенту; 
- $\quad$ надавати право академічним бібліотекам та подібним інститутам дистанційно звернутися до творів через закриті електронні мережі для цілей дослідження та приватного вивчення;

- прояснити дію вилучення «раnorama exception» (вільне створення та завантаження зображень об'єктів архітектури та скульптури, розміщених у публічному просторі), в т.ч. для нових каналів розповсюдження;

- модернізувати правила про примусові збори (за приватне копіювання), оскільки аналіз показує, що вони можуть спричиняти шкоду Єдиному ринку, споживачам та іншим ринковим гравцям; необхідно, щоб розподіл зібраних коштів між правовласниками був більш ефективним.

3) Досягнення ефективно функціонуючого ринку для об'єктів авторського права. Різноманітність контенту і його доступність споживачам повинні супроводжуватись ефективними правами творців контенту на отримання винагороди за свою працю. Ринок, особливо цифровий, часто не дозволяє правовласникам самим встановлювати ліцензійні умови і проводити переговори на справедливій основі. Наприклад, онлайн-платформи і агрегатори контенту не завжди в своїй діяльності слідують інтересам правовласників і принципам авторського права. Цьому є і юридичні причини (протиріччя в розумінні термінів «повідомлення та доведення для загального відома», що використовуються в цифрових транзакціях), і ринкові (авторам і виконавцям може не вистачати стійкості, щоб відстоювати своє право на справедливу винагороду).

Нарешті, платформи часто, посилаючись на посередницький характер своїх функцій, претендують на імунітет проти відповідальності за порушення прав інтелектуальної власності. У цьому випадку вони отримують вигоду від чужого контенту, але не забезпечують задоволення інтересів творців такого контенту. Слід вирішити, чи треба коригувати правила про імунітет для різних типів посередників.

Європейська комісія планує:

- оцінити, чи мають потребу в уточненні визначення прав «на повідомлення для загального відома» $\mathrm{i}$ «на доведення до загального відома»;

- вивчити необхідність створення особливих правил роботи новинних агрегаторів;

- досліджує, яких змін вимагають системи винагороди авторів і виконавців, щоб підвищити їх правову визначеність, прозорість і збалансованість.

4) Забезпечення ефективної і збалансованої правозастосовчої системи.

Недотримання прав авторів і виконавців завдає істотної шкоди і їм, і економіці в цілому.

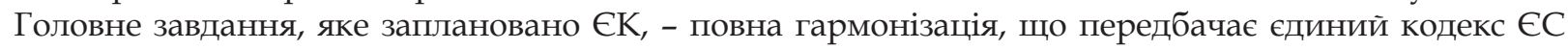
про авторське право, єдину юрисдикцію розгляду спорів і формування єдиного європейського авторського права. Наразі розглянемо чотири нові директиви і регламенти.

Частина пропонованих змін втілена в проектах, розглянутих раніше (наприклад, в проекті Регламенту про забезпечення транскордонної мобільності онлайнових контент-сервісів на внутрішньому ринку і в проекті Директиви щодо надання аудіовізуальних медіа-послуг в світлі мінливих ринкових умов). Розглянемо пакет пропозицій в сфері авторського і суміжного права, опублікований 14 вересня 2016 p.

У Повідомленні «Просуваючи справедливу, ефективну та конкурентну загальноєвропейську економіку, засновану на авторському праві, на цифровому Єдиному Ринку» (Promoting a fair, efficient and competitive European copyright-based economy in the Digital Single Market) Європейська комісія ще раз коротко перераховує основні кроки, викладені в попередньому повідомленні від 09.12.2015 p. «У напрямку до сучасного, більш європейського авторського права» [12].

Пройшли обговорення з різними учасниками про те, як підвищити доступність контенту. Розглянуті такі інструменти, як ліцензійні онлайн-хаби і каталоги творчої продукції; стандартизовані ідентифікатори контенту, сумісні з альтернативними; загальноєвропейська система пошуку контенту, що включає пошук по національних базах даних; поширення правовласниками їх творів на всій території ЄC за програмою Creative Europe MEDIA; фінансування виготовлення субтитрів і дубляжу до аудіовізуальних творів; різноманітні сервіси з рекомендацій по пошуку контенту.

Перегляду потребує система винятків з авторського права. Чинні винятки носять диспозитивний характер, не мають транскордонної дії і не відображають технологічних змін.

Окремий блок змін торкнеться заходів з примусового здійснення прав інтелектуальної власності. Проведена ЄК публічна консультація показала, що Директива 2004/48/ЄС недостатньо захищає від порушень, особливо в цифровій сфері. ЄК підготує зміни, які прояснять застосування попередніх і превентивних заходів захисту, судових заборон, а також правил розрахунку і розподілу збитків.

Комісія пропонує механізм, який дозволяє здійснювати заходи судового захисту та запровадити судові заборони, присуджені в одній з держав-членів, в інших державах-членах, де ті ж особи 
здійснюють аналогічні порушення. В умовах технологій, що розвиваються, особливо онлайн-, вкрай важливо, щоб суд якомога швидше і ефективніше розглядав питання про заходи захисту. СК розглядає варіанти відповідного регулювання - наприклад, за допомогою спеціалізації суддів. Нарешті, Комісія вивчить способи активного залучення до боротьби з піратством інформаційних посередників, і ще раз підніме питання про межі їх відповідальності, коли пропоновані посередниками сервіси використовуються для масових порушень, а посередники не перешкоджають цьому.

Як висновки, можливо зазначити наступне. Реформування вищевикладених аспектів права ЄС має бути відображене також в праві України. Аналіз науково-практичних та правових джерел свідчить, що пріоритетним завданням інформаційної політики України має стати розвиток інформаційного суспільства - як запоруки соціально-економічного розвитку населення і вирішення низки глобальних проблем сучасності. При цьому, наступні складові мають бути вирішені на законодавчому рівні:

- охорона прав інтелектуальної власності у цифровому середовищі. Характерним для СС у 20082016 роках стало здійснення значного кола досліджень, обговорення напрямків розвитку та законодавчих пропозицій з багатьох питань охорони авторського права і суміжних прав у цифровому середовищі. Вказана практика є особливо актуальною для України, де у порівнянні з СС лише у грудні 2016 р. було представлено проект «Цифрової адженди України - 2020» .

Слід зазначити, що пріоритети у галузі охорони авторського права і суміжних прав у цифровій економіці не знайшли відображення в Угоді про асоціацію між Україною та ЄС. Не прийнято документів щодо стратегії або концепції розвитку цієї сфери.

В той же час, практика використання творів та об'єктів суміжних прав в Україні, а також накопичення значного обсягу проблем, свідчать про необхідність:

- підготовки Концепції охорони прав інтелектуальної власності у цифровому середовищі;

- визначення на державному рівні бачення (у вигляді стратегії, концепції, програми) оцифрування культурної спадщини з врахуванням досвіду СС щодо сирітських творів, а також вирішенням проблеми стосовно творів, що не є у комерційному обігу або вільному доступі.

- зокрема, потребує суттєвої конкретизації та доповнень стосовно створення цифрових бібліотек та охорони авторського права;

Зазначимо, що в Україні - на відміну від ЄС, не здійснені базові зміни законодавства, не розвинуто укладання добровільних угод щодо можливостей здійснення оцифрування творів та їх поширення.

Відсутні також декларації, кодекси поведінки, організаційні заходи поводження 3 творами, що перейшли у суспільне надбання та оцифровуються, - 3 метою запобігання перекрученню авторства, порушення цілісності твору, запобігання технічним обмеженням використання таких творів. Законодавством не визначені такі права бібліотек, як можливість надання доступу до творів у цифровій формі з метою проведення досліджень або навчання через спеціалізовані термінали, встановлені в приміщеннях бібліотеки (аналогічні права визначені п.5(3)(n) Директиви № 2001/29/ЄС від 22.05.2001 тощо.

- прийняття змін до законодавства з застосування ліцензій відкритого доступу. Наразі відсутня можливість застосування ліцензій відкритого доступу в Україні, що пов'язано з відсутністю можливості укладання ліцензійних договорів щодо розпорядження майновими правами інтелектуальної власності в іншій, ніж письмова, формі. Відповідно до другої частини ст. 1107 ЦК України «у разі недодержання письмової форми договору щодо розпорядження майновими правами інтелектуальної власності такий договір є нікчемним». У 2015, 2016, 2018-19 рр. до Верховної Ради України депутатами, а також Кабінетом Міністрів України були внесені проекти законів з врегулювання цього питання. Проте на грудень 2019 р. зміни прийняті не були.

Аналіз Директиви 2001/29/ЄС свідчить, що в цілому рівень захисту авторського права і суміжних прав у інформаційному суспільстві в Україні відповідає рівню, встановленому в СС.

При перегляді Закону України «Про авторське право і суміжні права» доцільним є взяти до уваги практику реалізації директиви у державах-членах, введення виключень щодо авторського права і суміжних прав, а також застосування технологічних засобів захисту.

Також слід вдосконалити врегулювання прав і обов'язків сторін, які у співробітництві або наданні взаємних послуг забезпечують публічне сповіщення та надання доступу (до загального відома) публіки до об'єктів авторського права і суміжних прав. Щодо положень Угоди про асоціацію - зазначимо, що у статтях 173-177, а також ст. 171 Угоди надані лише окремі вибрані положення Інформаційної директиви.

Охорона «сирітських» творів. Вказаний інститут (Директива 2012/28/ЄС) не врегульовано законодавством України, запровадження охорони «сирітських» творів в Україні беззаперечно є актуаль- 
ним, враховуючи оцифрування національного культурного контенту та створення цифрових бібліотек .

В українському інформаційному законодавстві $є$ великі прогалини - нечітко регламентовані положення законодавства про інформаційні права, про охорону персональних даних, про телебачення. Вимагають доповнень закони про охорону авторських і суміжних прав, про засоби масової інформації, про участь в міжнародному інформаційному обміні. Також, всі більш актуальним стає регулювання вже розпочатого процесу концентрації власності вітчизняних засобів масовий інформації, злиття друкованих медіа, об'єднання їх з телеканалами, інформаційними агентствами, фінансовими групами. Не встановлені правила придбання та експлуатації інформаційних і телекомунікаційних технологій в державних установах, комп'ютерні та інформаційні системи не роблять очікуваного внеску в підвищення ефективності діяльності держорганів. Досить актуальною є розробка нормативних документів, що регламентують продаж інформаційних ресурсів, створюваних державними органами. Ресурси, які не підлягають роздержавленню (як статистична інформація), повинні бути чітко перераховані.

Нарешті, необхідно визначитися, які місце і роль України в міжнародних програмах, типу Глобальної інформаційної інфраструктури.

В ряді документів, підготовлених за останні 20 років щодо розвитку сектору ІКТ в Україні та розбудови інформаційного суспільства, зазначалось і можна зазначити це і на даний час - що разом 3 певними досягненнями, ступінь розбудови інформаційного суспільства в Україні є недостатньою і не відповідає потенціалу та можливостям України.

1. Communication from the Commission to the European Parliament, the Council, the European Economic and Social Committee of the Regions. Upgrading the Single Market: more opportunities for people and business. COM/2015/0550 final. URL: https://ec.europa.eu/growth/single-market/strategy_en

2. Shaping the Digital Single Market. Review by the European Commission. URL: https://ec.europa. eu/digital-single-market/en/policies/shaping-digital-single-market

3. Rosati E. Do ask, do tell, do nothing: the EU Commission and all those copyright consultations. URL: https:/ / academic.oup.com/jiplp/article/9/10/785/2910831

4. Communication from the Commission to the European Parliament, the Council, the European Economic and Social Committee of the Regions. Digital Single Market Strategy for Europe/* COM/2015/0192 final. URL: https:/ / eur-lex.europa.eu/legal-content/EN/TXT/?uri=CELEX\%3A52015DC0192.

5. EC Regulation on cross-border parcel delivery services. URL: https://ec.europa.eu/growth/sectors/postal-services/parcel-delivery_en

6. Proposal for a regulation of the European Parliament and of the Council on cross-border parcel delivery services COM/2016/0285 final - 2016/0149 (COD). URL: https://eur-lex.europa.eu/legal-content/ EN/TXT/?uri=COM:2016:0285:FIN

7. Communication from the Commission to the European Parliament, the Council, the European Economic and Social Committee of the Regions Upgrading the Single Market: more opportunities for people and business COM/2015/0550final. URL: https://eur-lex.europa.eu/legal-content/EN/TXT/?uri=CO M\%3A2015\%3A550\%3AFIN

8. Communication from the Commission to the European Parliament, the Council, the European Economic and Social Committee of the Regions. A European agenda for the collaborative economy COM/2016/0356 final. URL: https:/ / eur-lex.europa.eu/legal-content/EN/TXT/ ?uri=COM:2016:356:FIN

9. Proposal for a Directive of the European Parliament and of the Council on certain aspects concerning contracts for the supply of digital content COM/2015/0634 final - 2015/0287 (COD) - adopted in 2019. URL: https:/ / oeil.secure.europarl.europa.eu/oeil/popups/ficheprocedure.do?lang=en\&reference=2015/0 288(COD).

10. Communication from the Commission to the European Parliament, the Council, the European Economic and Social Committee of the Regions. Towards a modern, more European copyright framework. COM/2015/0626 final URL: https://ec.europa.eu/transparency/regdoc/rep/1/2015/EN/1-2015-626EN-F1-1.PDF

11. Directive 2001/29/EC of the European Parliament and of the Council of 22 May 2001 on the harmonization of certain aspects of copyright and related rights in the information society, Official Journal L 167 , 22/06/2001 P. 0010 - 0019. URL: https://eur-lex.europa.eu/LexUriServ/LexUriServ.do?uri=CELEX: 32001L0029:EN:HTML 
12. Communication from the Commission to the European Parliament, the Council, the European Economic and Social Committee of the Regions. Promoting a fair, efficient and competitive European copyright-based economy in the Digital Single Market COM/2016/0592 final. URL: https://eur-lex.europa.eu/ legal-content/EN/TXT/?uri=CELEX:52016DC0592.

\section{Summary}

The article is devoted to the large-scale changes and improvement of legal regulation of the single European market, and especially its digital segment. The directions of such reform are being considered - development of data economy and online business projects, accessibility of content to users, protection of interests of authors. New regulations, directives and notices from the European Commission on market analysis and change assessment have been identified. Consideration has also been given to the substantially updated copyright and related legislation.

The core documents define the Digital Single Market Strategy and include reform projects:

- copyright and related rights;

- rules for regulating digital contracts;

- principles of enforcement of copyright and consumer rights.

The Internet and digital technologies, having been transformed from a separate sector of economy into the basis of the whole innovative economic system, change the way of life and work of every person, enterprise, society as a whole. The created national digital markets in each European country will be more effective after being united into a single European market. The Digital Single Market (DSM) is a market in which the free movement of goods, labor, services, capital are ensured, and in which individuals and businesses can equally access and operate online on an equitable basis competition, a high level of consumer protection and personal data, regardless of their nationality or location.

Reforming the above aspects of the EU law should also be reflected in the Ukrainian legislation. The analysis of scientific, practical and legal sources shows that the priority of the information policy of Ukraine should be aimed at development of the information society - as a guarantee of socio-economic development of the population and the solution of a number of global problems of the present as well as entering European information society. In doing so, the following components must be addressed at the legislative level:

- protection of the intellectual property rights in the digital environment. Significant for the EU in 20082016 was the implementation of large number of researches, discussion of the development trends and legislative proposals on many issues of the copyright and related rights in the digital environment. This practice is being especially relevant for Ukraine, where in comparison with the EU only in December 2016 the project "Digital Agendas of Ukraine - 2020" was presented. 